\title{
Epidemiology of West Nile in Europe and in the Mediterranean Basin
}

\author{
Paolo Calistri ${ }^{*}, 1$, Armando Giovannini ${ }^{1}$, Zdenek Hubalek ${ }^{2}$, Aurelia Ionescu ${ }^{3}$, Federica Monaco ${ }^{1}$, \\ Giovanni Savini ${ }^{1}$ and Rossella Lelli ${ }^{1}$ \\ ${ }^{1}$ Istituto Zooprofilattico Sperimentale dell'Abruzzo e del Molise "G. Caporale”, Teramo, Italy \\ ${ }_{2}^{2}$ Institute for Vector Biology, Brno, Czech Republic \\ ${ }^{3}$ Institute of Diagnosis and Animal Health, Bucharest, Romania
}

\begin{abstract}
In the last 30 years several cases of West Nile (WN) virus infection were reported in horses and humans in Europe and in the Mediterranean Basin. Most of them were determined by strains of the Lineage 1 included in the European Mediterranean/Kenyan cluster. Strains of this cluster are characterised by a moderate pathogenicity for horses and humans and limited or no pathogenicity for birds. In recent years, however, WN cases determined by strains grouped in the Israeli/American cluster of Lineage 1 or in the lineage 2 have been reported in Hungary and Austria. The role of migrating birds in introducing new viruses to Europe has been often demonstrated. The migratory birds, which may be infected in their African wintering places, carry the virus northward to European sites during spring migrations. In the past, the virus introduction determined occasional cases of WN. In the recent years, new epidemiological scenarios are developing. In few occasions it has been evidenced the capability of WNV strains of overwintering by using local birds and mosquitoes. Species of Culex amongst mosquitoes and magpies (Pica pica), carrion crows (Corvus corone) and rock pigeons (Columba livia) amongst resident birds are the most probable species involved in this hypothetical WND endemic cycle.
\end{abstract}

Keywords: Epidemiology, Europe, Mediterranean Basin, West Nile.

\section{INTRODUCTION}

West Nile virus (WNV) is a mosquito-borne Flavivirus belonging to the Japanese encephalitis antigenic complex in the family Flaviviridae [1]. WNV has been detected in Africa, Europe, Middle East, Asia, Oceania (subtype Kunjin) and, more recently, in the New World [2,3].

The natural cycle of the infection involves birds and mosquitoes, particularly Culex spp. and Aedes spp. [4, 5]. Many species of wild birds might act as amplifying hosts [6], whereas humans, horses and other mammals are considered incidental or dead-end hosts [2]. Although neurological disease in both humans and horses was reported since late 1950s [7], the infection in humans and horses mainly occurs asymptomatically or with mild febrile illness $[8,9]$. In humans the morbidity and severity of symptoms depend on several factors, including the WNV strain involved and the immune status of the patient [10]. The ecologic aspects of WNV infection, involving mosquitoes, birds, and humans, were first described in the 1950s in Egypt [11]. In the last 30 years several cases of West Nile infection in horses and humans were reported in Europe and in the Mediterranean Basin. Several studies were able to detect the virus circulation in wild birds and mosquitoes, giving a substantial contribution to a more clear picture of WNV circulation in the Old Continent. Despite the studies performed on the ecological patterns involved in the WNV transmission, the

*Address correspondence to this author at the Istituto Zooprofilattico Sperimentale dell'Abruzzo e del Molise "G. Caporale", Teramo, Italy; Tel: +39 0861 332241; Fax: 390861 332251;

E-mail: p.calistri@izs.it mechanisms of virus introduction and spread in Europe and in the Mediterranean Basin are not fully understood. The aim of this paper is to review the main epidemiological findings on WNV occurrence in Europe and in the Mediterranean Basin in the last 30 years, with an attempt of defining possible trends in the epidemiology of West Nile in Europe for the next years.

\section{WEST NILE IN EUROPE AND IN THE MEDITERRANEAN BASIN: 1979-2009}

In the last decades cases of West Nile infection in horses and humans were often notified in Europe and in the Mediterranean Basin [4, 12]. These events gave the possibility to better understand the ecology of WNV in the European environment. Alongside with the classical epidemiological approach, the application of the recent technology in the diagnostic field consented to analyse the genome of the strains involved in the outbreaks. It was possible to compare the RNA sequences of novel isolates with those of existing strains from known locations and dates, to identify individual virus lineages and the presence of mismatches that modify genome segments between different parental strains. Smaller differences in RNA sequences could be detected even within consecutive outbreaks and it is now possible to track the spatial and temporal spread of individual viruses in a manner that was previously impossible using conventional serological assay alone. Phylogenetic relatedness of the WNV segregates the isolates in two main lineages, the lineage 1 which is composed of WNV strains from Europe, North America, North Africa and Australia and lineage 2 which contains strains historically isolated in sub-Saharan Africa and 
Madagascar that are considered non-pathogenic in human and horses. A third lineage has been recently proposed to include the Rabensburg virus, an European strain isolated in Czech Republic and a fourth independent lineage which comprises an isolate from Caucasus [13].

The majority of the strains responsible of the European and the Mediterranean Basin outbreaks were in the Lineage 1. Most of them are grouped in a cluster called European Mediterranean/Kenyan cluster [14]. Some others, especially those responsible for the Israeli outbreaks were within the Israeli/American cluster (Fig. 1). Clusters might have an important impact on the strain pathogenicity. Strains belonging to the European Mediterranean/Kenyan cluster are characterised by a moderate pathogenicity for horses and humans and limited or no pathogenicity for birds. Conversely, strains grouped in the Israeli/American cluster are characterised by high rates of avian deaths and, in the United States, also by high rates of illness and deaths in humans and horses [15]. Lineage 2 strains include strains endemic to sub Saharian Africa and have been so far considered of low pathogenicity. Nevertheless recent data demonstrated that South African strains belonging to lineage 2 were able to induce severe clinical symptoms in both humans and horses [16] and the presence of neuroinvasive phenotypes, as demonstrated in a murine model, strengthened the evidence that pathogenicity does not necessarily overlap the phylogenetic segregation. In the following paragraphs the main outbreaks or evidence of WNV circulation occurring in Europe and in the Mediterranean basin are described according to their geographic locations and virus lineage belonging (Table 1). The main geographical areas involved by WNV transmission are shown in Fig. (2).

\section{OUTBREAKS CAUSED BY LINEAGE 1 WND STRAINS}

\section{European Mediterranean/Kenyan Cluster}

\section{Northern Africa}

Between August and September 1994 a WN epidemic occurred in Algeria. About 50 cases were suspected in a village of the Timimoun oasis in the central Sahara. Twenty of them were cases of encephalitis. The infection caused the death of 8 patients [12]. Two years later, from August to October, a WN outbreak was described in horses of Kenitra and Larache provinces in Morocco. The infection affected 94 animals and 42 of them died [17]. Between September and December 1997, in Tunisia, 173 patients were hospitalised with symptoms of meningitis and meningo-encephalitis in the districts of Sfax and Mahdia [12, 18]. Eight deaths were reported. In 2003, in Morocco, in the same area where the 1996 outbreak occurred, 9 cases of encephalitis, with 5 deaths, were reported in horses [14].

\section{Eastern Europe}

From July to October 1996, 393 patients in Bucharest and other south-eastern regions of Romania were serologically confirmed to have been infected by WNV. Of them, 352 showed nervous symptoms of acute central nervous system infection. Seventeen patients died [19]. After that first large epidemic further investigations in the following years confirmed the virus circulation in humans $[20,21]$ in birds and horses $[22,23]$. In 1997, one year after the Romanian outbreak, five human cases were confirmed in Breclav area (South Moravia region) in Czech Republic from June to September 1997 [24]. In the same time the virus was also isolated from mosquito pools [24, 25].

Between July and October 1999, a large outbreak occurred in the city of Volgograd (Russia) where 826 patients were admitted to hospitals with the clinic diagnosis of acute aseptic meningo-encephalitis [26]. Blood samples taken from 318 of the patients confirmed the WNV infection in 183 cases, including 40 fatal cases [26].

Further investigations in wild bird populations in wetlands of Southern Moravia in Czech Republic, between 2004 and 2006, serologically confirmed the presence of infection in $13(3.3 \%)$ of 391 tested birds. The positive individuals belonged to 11 species: common coot (Fulica atra), common kingfisher (Alcedo atthis), reed warbler (Acrocephalus scirpaceus), sedge warbler (Acrocephalus schoenobaenus), marsh warbler (Acrocephalus palustris), Savi's warbler (Locustella luscinioides), reed bunting (Emberiza schoeniclus), blackcap (Sylvia atricapilla), penduline tit (Remiz pendulinus), blue tit (Parus caeruleus) and starling (Sturnus vulgaris) [27]. Information on further human cases in 2005 and 2006, in Astrakhan and Rostov regions (Russia) respectively, was dispatched through ProMed mailing system [28, 29].

\section{Western Europe}

Between 1962 and 1965, human and equine cases were detected in the Camargue region (France), and the virus was isolated from Culex modestus mosquitoes [30-34]. Before 1970, an epizootic of equine encephalomyelitis was recorded in Southern Portugal. Neutralizing antibodies against WNV were detected in $29 \%$ of the surviving animals [35]. In 1971, in the same country, WNV was isolated from Anopheles maculipennis s.l. mosquitoes [36]. In 1979, WNV infection was suspected in the Ebro Delta (Spain) [35], and 19 years later more recent studies confirmed the presence of antibodies against WNV in the human population living in that area of Spain [37]. In the late summer of the same year WNV infection was first evidenced in horses residing in proximity of Fucecchio marshes, a wetland area in the Val di Nievole Valley, Tuscany, Italy [38]. The disease affected 14 horses, six of which succumbed. No cases of human encephalitis were reported.

In the Camargue area (France) between September to November of the 2000 , the WNV infection was laboratory confirmed in 76 equines out of 131 animals with neurological disorders [8]. The outbreak caused the death of 21 animals. In 2003 further cases were described in humans and horses [39] and in 2004 the disease was reported in horses [40]. In the same year a case of aseptic meningitis due to WNV was diagnosed in Spain [41]. In 2004 a study performed on migratory common coot (Fulica atra) in the Doñana natural park (Andalusia, south-western Spain) revealed the presence of neutralising antibodies in birds caught during 2003, 2004 and 2005 [42]. Seroconversion was demonstrated in re-captured birds supporting the hypothesis of the local circulation of the virus [41]. A further 


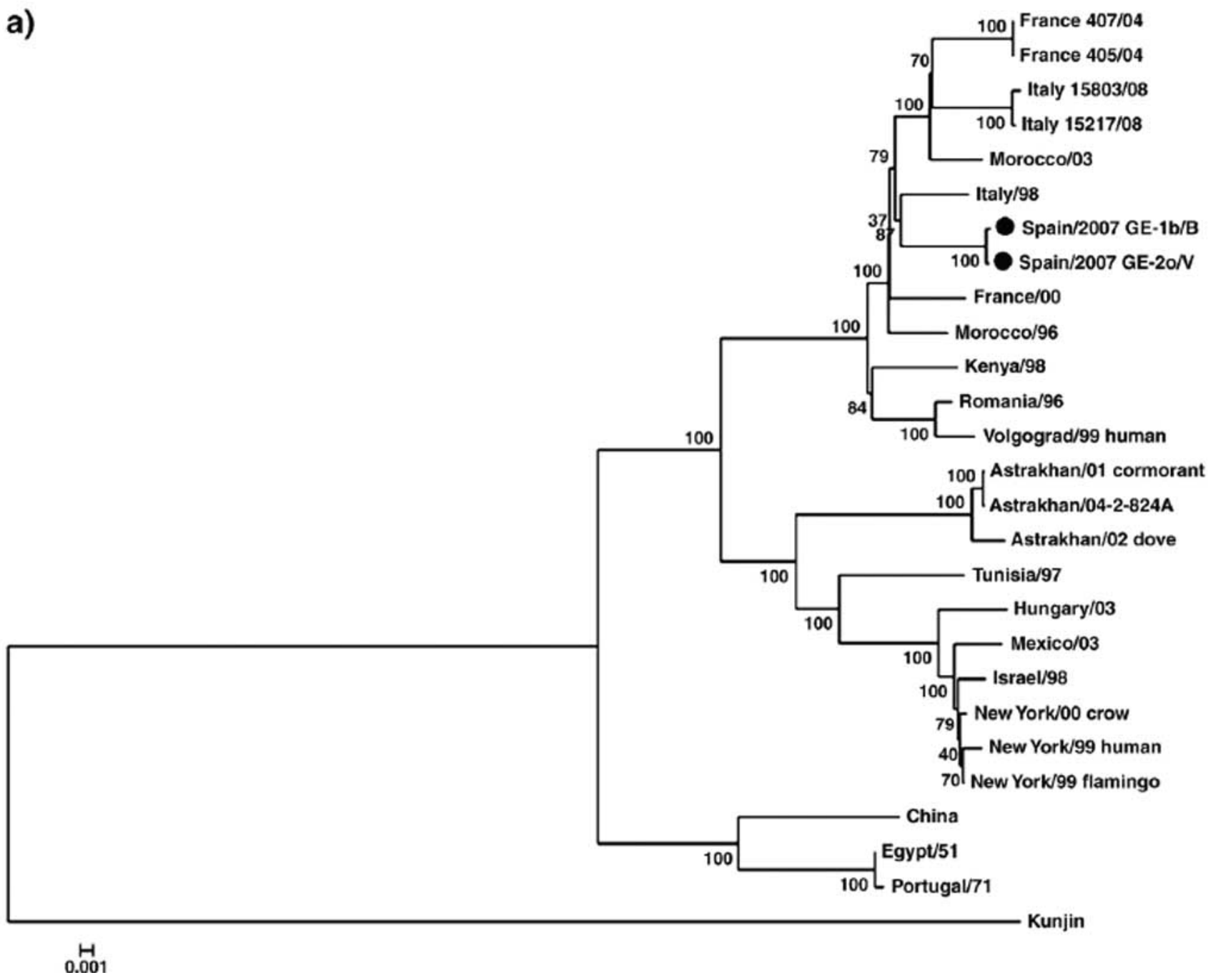

Fig. (1). Phylogenetic tree based on complete genomes of West Nile virus belonging to lineage 1. Adapted from Sotelo et al., 2009.

study found neutralising antibodies in several species of wild migratory birds in southern Spain [43]. A comparative study between the levels of neutralising antibodies against WNV found in migratory (short distance or trans-Saharan) and resident bird species was performed in 2004 near Seville [44]. Antibodies were found in 3 species of long-distance trans-Saharan migratory birds (Lanius senator, Phoenicurus phoenicurus, Sylvia borin) and in one resident bird species (Turdus merula). This observation confirmed the importance of migratory birds in introducing WNV in the country, but also supported the hypothesis of a local viral circulation.

During the same summer, WNV genomic RNA was detected in Culex pipiens and Cx univittatus mosquitoes by reverse transcription-polymerase chain reaction (RT-PCR) in six out of 57 mosquito pools collected in Southern Portugal. Phylogenetic analysis demonstrated a close relationship with WNV strains circulating in the Mediterranean basin (Italy, 1998; France, 2000; Morocco, 2003) [45]. In the summer 2004, two linked WNV cases were also reported in tourists in the Algarve, Portugal [46] and WNV was isolated from Culex pipiens s.1. and Cx. univittatus mosquitoes [45]. Two years later, 4 equine cases of WNV infection were reported in Argeles sur mer in the French Department of PyrénéesOrientales (France) [47].

In August 2008, after ten years of silence, a large epidemic outbreaks affected eight Provinces in three Italian Northern Regions (Emilia Romagna, Veneto, Lombardy) [48] where a total of 794 cases of WNV infection in 251 equine stables were detected on the basis of the clinical signs and as a result of a serological screening in horses living in the area. Only 32 of the serologically positive horses showed clinical signs, and 5 of them died $[49,50]$. Significant levels of positivity by RT-PCR were also observed in magpies (Pica pica) $(9.1 \%$, 95\% confidence levels: 6.1-13.4\%), carrion crows (Corvus corone) $(7.4 \%, 95 \%$ confidence levels: 3.6-14.4\%) and rock pigeons (Columba livia) (12.9\%, 95\% confidence levels: 7.6-21.2\%). Nine human cases of WNF, four of which characterized by neuroinvasive symptoms, were detected during 2008 [51, 52]. The phylogenetic analysis of the isolates indicates a $98.8 \%$ nucleotide similarity with the strain isolated in Tuscany during the 1998 [49, 53]. In 2009 a new epidemic reemerged mostly in the same 2008 outbreak area with new foci of infection in Central Italy. 
Table 1. Report of the West Nile Disease Outbreaks in European Union and Bordering Countries

\begin{tabular}{|c|c|c|c|c|}
\hline \multirow[t]{2}{*}{ Country } & \multirow[t]{2}{*}{ Year } & \multicolumn{3}{|c|}{$\begin{array}{l}\text { Species Involved/ } \\
\text { Clinical Symptoms }\end{array}$} \\
\hline & & Human & Equine & Birds \\
\hline Algeria & 1994 & Yes & & \\
\hline Austria & 2008 & & & NK \\
\hline Croatia & 2001-2002 & & No & \\
\hline \multirow{2}{*}{$\begin{array}{l}\text { Czech } \\
\text { Republic* }\end{array}$} & 1997 & Yes & & \\
\hline & 2004-2006 & & & No \\
\hline \multirow{2}{*}{ France* } & 2000 & & Yes & \\
\hline & 2003-2004-2006 & Yes & Yes & \\
\hline Greece & $1970-1980$ & & No & \\
\hline Hungary & $2003-2008$ & Yes & & \\
\hline \multirow{2}{*}{ Israel } & 1998-1999 & & Yes & Yes \\
\hline & 2000 & Yes & & \\
\hline \multirow{2}{*}{ Italy* } & 1998 & No & Yes & No \\
\hline & 2008-2009 & Yes & Yes & No \\
\hline Morocco & $1996-2003$ & & Yes & \\
\hline Poland & 2006 & & & No \\
\hline \multirow{2}{*}{ Portugal } & $1971 *$ & & & \\
\hline & 2004* & Yes & & \\
\hline Romania & From 1996 & Yes & Yes & Yes \\
\hline Russia & 1999-2005-2006 & Yes & & \\
\hline \multirow{2}{*}{ Spain } & $2003-2005$ & & & No \\
\hline & 2004 & Yes & & \\
\hline Tunisia & 1997 & Yes & & \\
\hline
\end{tabular}

Yes: presence of clinical symptoms; No: absence of clinical symptoms; NK: not known.

* WNV detected in mosquitoes.

\section{Israeli/American Cluster}

Several WNF human cases were notified in Israel in the 1950s [12]. However no reports of WNV circulation are available in Israel since 1957. In 1998 the virus was isolated from the brain of a stork [54] and clinical signs were reported in horses. In 1999, thousands of geese were destroyed when the infection was found in a commercial flock [55]. A further large epidemic in human was reported from August to October 2000, with 417 laboratory confirmed cases [56, 57]. Between 2003 and 2007, a yearly average of six cases of WNV neuroinvasive infection in humans were diagnosed in Hungary [58]. In the same country 14 human cases were reported during August and September 2008 [58].

\section{Outbreaks Caused by Lineage 2 WND Strains}

In 2004 a WNV strain correlated to the Central Africa lineage 2 viruses was isolated from a goshawk (Accipiter gentilis) in Hungary and in 2008 from two free-living sparrow hawks (Accipiter spp.) and one captive kea (Nestor notabilis) in the Lower Austria (Niederosterreich) and Vienna (Wien) regions, respectively [59]. It was the first time that viruses of the lineage 2 were reported in Europe. These events further emphasize the ability of these viruses to be transmitted by migratory birds outside the traditional niches of viral circulation and to adapt to local vectors [13].

\section{Serological Evidence of WNV Circulation in Europe}

Further evidences of WNV transmission were observed in Albania (in 1958 in humans), in Eastern Bulgaria (19601970 in humans and birds), in Belarus (in 1977 in humans), in Ukraine (in the 1970s and in 1985 in humans) and in Moldavia (in the 1970s in humans) [4]. In Greece serological studies detected WNV antibodies in animals (rabbits, goats, cattle, horses) and humans in the 1970s and 1980s [60], but an intensive surveillance on blood donor samples in 2006 and 2007 failed to reveal any positive result [61]. The presence of WNV infection in Croatia was serologically confirmed in Dakovo region (Eastern Croatia) in 4 out of 980 tested horses during the end of the 2001 and the beginning of 2002 [62]. At the moment it represents the only notification of WNV circulation in the Former Yugoslavia countries. In 2006, a serological survey was carried out on 78 horses, 20 domestic chickens, and 97 wild birds belonging to 10 species from different areas in Poland. Specific antibodies were detected in 5 juvenile (hatchingyear) birds: 3 white storks (Ciconia ciconia), one free-living mute swan (Cygnus olor) and one hooded crow (Corvus corone cornix) [63].

\section{The Ecological Factors Associated with the WNV Transmission}

WNV is maintained in an enzootic cycle, transmitted primarily between avian hosts and mosquito vectors [10]. The role of migratory birds in relation to the introduction of virus into Europe and the Mediterranean Basin is clearly assessed by numerous studies in Spain [42-45, 64, 65], Israel [66], Poland [63], Romania [23] and Czech Republic [27]. Based on the phylogenetic analysis and comparison of full length genomes of WNV isolates from 1971 and 2004, the occurrence of repeated introductions has also been suggested in Portugal [67].

According to this hypothesis the migratory birds, which may be infected in their African wintering places, are carrying the virus northward during spring migrations to European sites. This hypothesis would explain why outbreaks often occur in or near wetlands and urban areas, where migratory bird populations, vectors and amplifying hosts are often contemporaneously present. It would also explain the timing of outbreaks, with the introduction of WNV in April and May during the northward spring birds migration, the following amplification of the virus through the infection of local bird populations and eventually the occurrence of viral infection in humans and equines from July to September [68]. Serological studies performed in Spain in 2004 near Seville [44] found specific antibodies against WNV in 3 species of long-distance trans-Saharan migratory birds (Lanius senator, Phoenicurus phoenicurus, Sylvia borin) and in one resident bird species (Turdus merula). The significant number of virological positive birds found in Italy in 2008 among magpies (Pica pica), carrion crows (Corvus corone) and rock pigeons (Columba livia) 


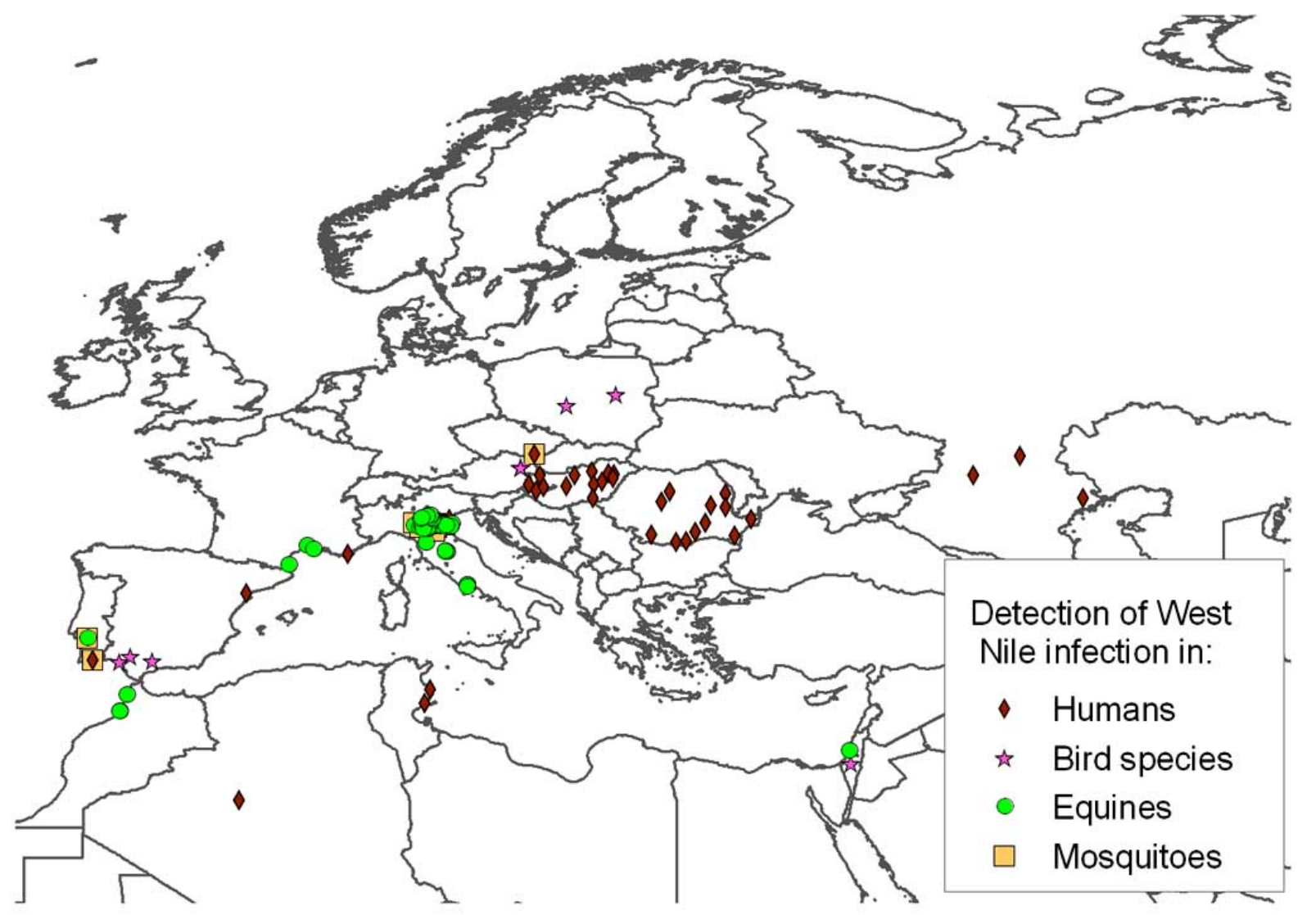

Fig. (2). Areas in Europe and in the Mediterranean Basin involved by West Nile virus transmission.

[50] suggests a possible role of these resident species in the maintenance of local virus transmission. At the moment the lack of data on the length and the load of viraemia in these species does not permit to make any solid inference on the possible contribution of these birds in WNV endemisation and in the maintenance of the infection during the interepizootic periods.

Regarding the virus transmission in the bird population, there is a possibility that WNV in crows [69] and geese [70] could be transmitted by means other than arthropod vectors. These studies, however, has been performed in USA with the 1999 New York and 1998 Israel strains. No similar findings were observed in the Old World with other WNV strains.

While the role of resident birds in WNV endemisation is not clear, more information is available in relation to the vectors. Vertical transmission of WNV in mosquitoes (i.e. passage of virus from infected female to her offspring) was demonstrated in the laboratory [71, 72] and in the field [73]. In addition, the detection of WNV in pools of overwintering hibernating Culex pipiens mosquitoes in New York City in 2000 [74] clearly indicates the capacity of the virus to overwinter and to survive in hibernating infected adult mosquitoes. The survival of adult mosquitoes during winter and even a certain level of adult activity were sometimes observed in the Mediterranean countries and in other temperate areas [75-77].

The enzootic cycle may persist in the same geographical areas from one year to the following without any apparent evidence of this transmission and without the occurrence of neurological cases in equines or humans. This phenomenon was frequently observed in several places in Europe (Spain, Austria, Portugal). In Italy, the surveillance activities carried out in 15 Italian wetlands from 2001 to 2007 were able to detect sporadic WNV circulation in several areas through seroconversions in both chicken and horse sentinel animals (Figs. 3, 4) [48, 78]. In all cases, this evidence of virus introduction and circulation was not followed by wider epidemics or by the occurrence of neurological cases neither in horses nor in humans. This is consistent with the observation that WNV infection is more strictly linked to wetlands and marshes with abundant bird populations, especially migratory birds $[43,66,67,79]$. The mechanisms governing the bridging of virus infection to human and equines populations are not fully understood. The role of ubiquitous mosquito species, feeding both on humans and birds, is considered to play an important role [9] and particularly the Culex pipiens species complex. It includes the pipiens and the molestus forms which are of varying degrees ornitophilic and anthropophilic forms, respectively, and can act as bridge vectors with a high potential for spreading WNV [80]. In Portugal, both the pipiens and the molestus forms have been found in sympatry with considerable degree of introgression, further heightening their importance as bridge vectors [81]. But also the role of resident birds like magpies and pigeons [50], frequent inhabitants of urban areas, should be clarified. Other and more general ecological, social and behavioural changes, which are increasing the frequency of contacts between 


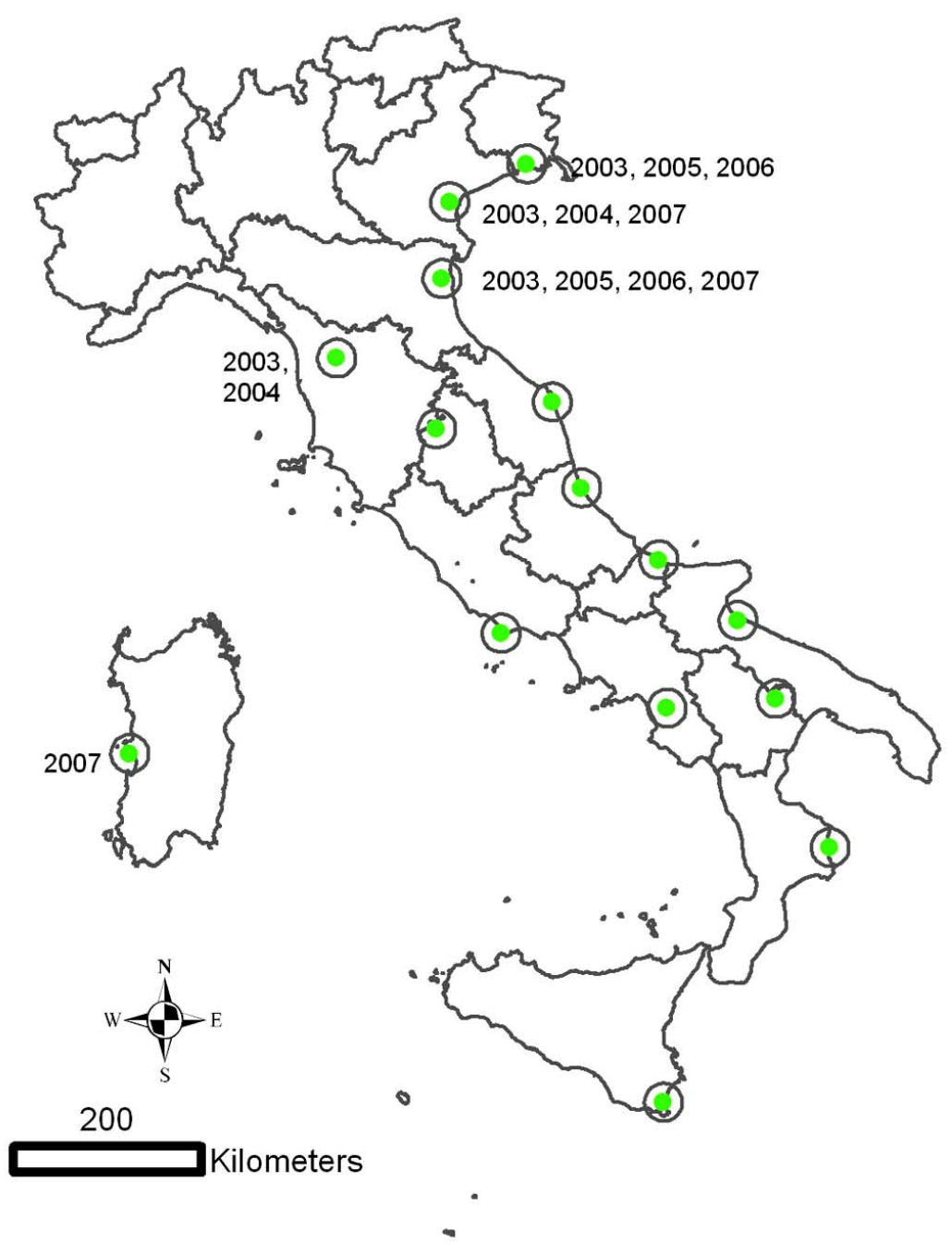

Fig. (3). Geographical distribution of the 15 Italian wetlands under surveillance for WNV circulation from 2001 to 2007. Years indicate places and time of ELISA IgG positive sentinel chickens.

humans and wildlife, might also facilitate the infection of humans.

Although the link between WNV and wetlands is clear, two large outbreaks were reported in Europe in highly inhabited urban areas: Bucharest [19] and Volgograd [26]. The majority of patients (61\%) affected during 1996 in Romania was living in the Bucharest urban area [19]. Culex pipiens was the predominant mosquito species found. Apartment blocks were found heavily infested because of the presence of leaking pipes and standing water in the basements [19]. In the epidemic in Volgograd in 1999, approximately $65 \%$ and $30 \%$ of human cases were from Volgograd and Volzhskii urban areas, respectively and only the other 5\% occurred in the rural region around Volgograd [26]. A large urban WN fever epidemic occurred also in New York City in 1999, with 59 hospitalised cases and 7 deaths [9]. The great capacity of the virus to cause large urban epidemics is confirmed by the observation of the increasing number of cases in urban counties in USA, with the result that urbanization is becoming an important risk factor for WNV disease incidence in USA [82].
It should be reminded, however, that humans and equines are accidental hosts and that dead-end hosts represent an efficient limiting factor to the survival of the infectious agent and their involvement is not fruitful from the evolutionary point of view [83].

\section{CONCLUSIONS}

The history of WNV transmission in Europe shows some distinctive characteristics [84]:

the human and equine outbreaks generally occur from July to September at or near wetlands or urban sites,

the most common vectors are mosquitoes of Culex genus, feeding mostly on birds and mammals,

birds are the primary vertebrate hosts. Many species can produce levels of viraemia sufficient for transmitting the virus to vectors,

in the majority of cases the infection is sporadic, as a consequence of the virus introduction through migratory birds from Africa, where the WNV extensively circulates [85-87], 


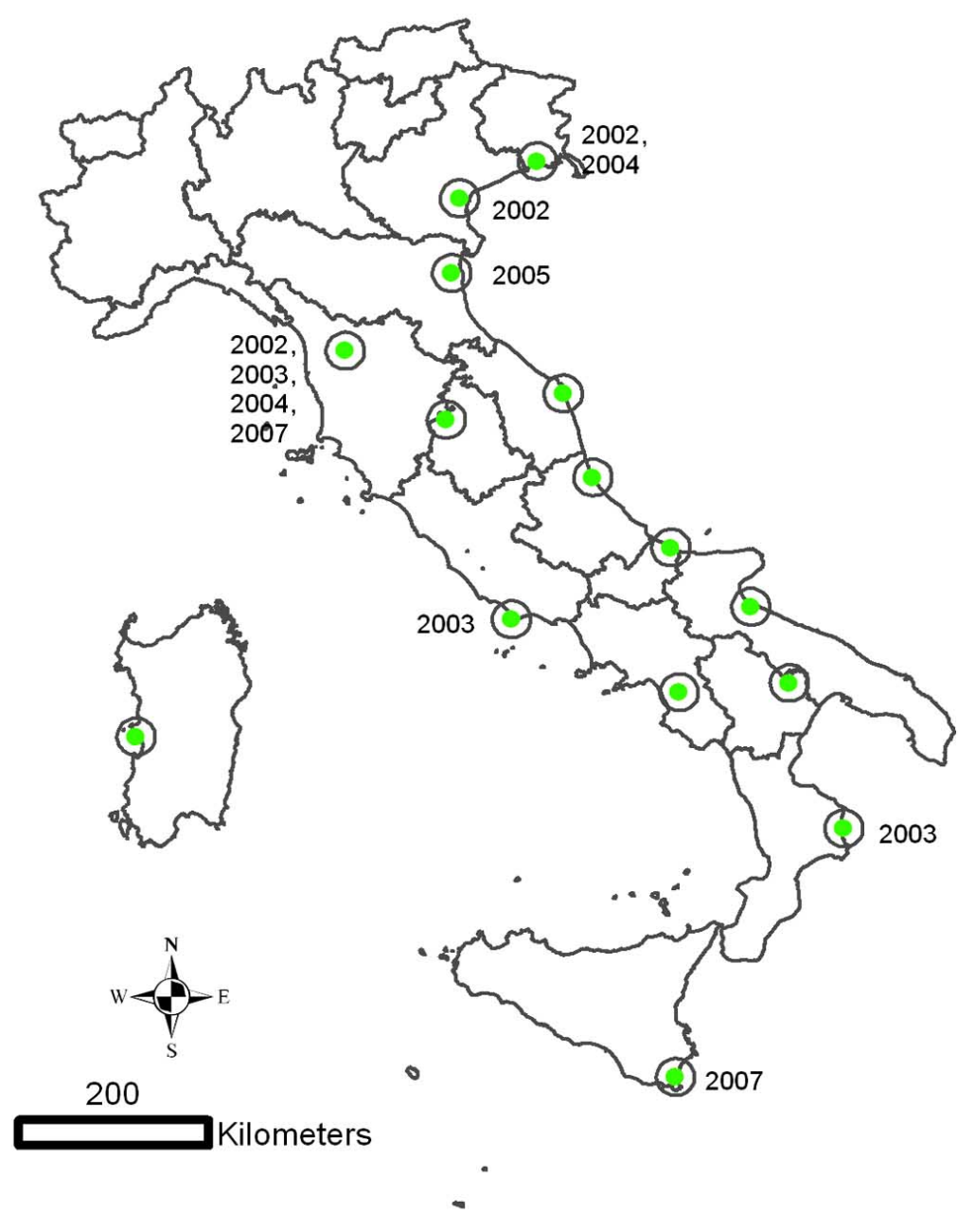

Fig. (4). Geographical distribution of the 15 Italian wetlands under surveillance for WNV circulation from 2001 to 2007. Years indicate places and time of virus neutralisation positive sentinel horses.

$>\quad$ the introduction of virus may result in local virus transmission in resident bird populations and sometimes in the involvement of equine and human populations.

The recent Romanian and Italian epidemiological scenarios, however, evidenced new possible developments of the WNV infection in Europe. In both cases the reoccurrence of $\mathrm{WN}$ in continuous years, in the same places, involving humans and equines, is likely to be linked to the endemisation of the infection in the territory rather than to a new introduction of the virus.

This observation may introduce new scenarios of risks for the Old Continent, especially if the WNV will be capable of spreading across wide territories: the area which is presently involved in the last Italian epidemic is about 34000 square kilometres wide, with a population of more than 30000 horse and 7 million of people.

More information is needed on the overwintering mechanisms that are taking place in Italy. Various mechanisms, in fact, may contribute to the virus endemisation [88]:

I. continuing enzootic transmission, which implies a continuous blood feeding activity by infected adult mosquitoes and the permanent presence of susceptible bird populations. These conditions might be fulfilled in temperate Mediterranean areas, where climate conditions may permit the continuing activity of mosquitoes and the presence of resident peri-urban birds species,

II. vertical transmission by Culex mosquitoes. Further experimental studies should be performed on the ability of WNV strains isolated in Europe to be vertically transmitted in autochthonous mosquitoes species. Winter entomological surveillance activities in the infected areas should be strengthened with the aim of detecting field evidence of vertical transmission in vectors,

III. overwintering infected mosquitoes. Overwintering dormancy (diapause) is a well-known mechanism in Culex pipiens $[76,77]$ which seems to have played a role in the overwintering of infection in 2000 in New York City [74]. At the moment, no data are available on the possible contribution of this mosquito behaviour in the endemisation of WNV infection in Europe, 
IV. chronic infection in birds. Long-term infection in birds has been described with other arboviruses [89], but no clear evidences of the existence of such mechanism are presently observed for WNV. Further studies on the pathogenesis of WNV infection in European resident bird populations should be performed.

In conclusion, the increasing detection of WNV transmissions in Europe and in the Mediterranean Basin may be partially due to the rising awareness to this infection, but the hypothesis of a true spread of the virus has not to be excluded and the possible consequences should not be underestimated. Further efforts are therefore needed to clarify the ecological and epidemiological patterns of the infection in the Old World as well as enhanced surveillance activities are required to monitor the WNV spread and to take appropriate and timely measures to protect the public health.

\section{REFERENCES}

[1] Karabatsos N. International catalogue of arboviruses, including certain other viruses of vertebrates. $3^{\text {rd }}$ ed. San Antonio: American Society of Tropical Medicine \& Hygiene 1985.

[2] Komar N. West Nile viral encephalitis. Rev Sci Tech 2000; 19: $166-76$.

[3] Lanciotti RS, Roehrig JT, Deubel V, et al. Origin of the West Nile virus responsible for an outbreak of encephalitis in the northeastern United States. Science 1999; 286: 2333-7.

[4] Hubalek Z, Halouzka J. West Nile fever--a reemerging mosquitoborne viral disease in Europe. Emerg Infect Dis 1999; 5: 643-50.

[5] Kulasekera VL, Kramer L, Nasci RS, et al. West Nile virus infection in mosquitoes, birds, horses, and humans, Staten Island, New York, 2000. Emerg Infect Dis 2001; 7: 722-5.

[6] Komar N, Panella NA, Burns JE, Dusza SW, Mascarenhas TM, Talbot TO. Serologic evidence for West Nile virus infection in birds in the New York City vicinity during an outbreak in 1999. Emerg Infect Dis 2001; 7: 621-5.

[7] Spigland I, Jasinska-Klingberg W, Hofshi E, Goldblum N. Clinical and laboratory observations in an outbreak of West Nile fever in Israel in 1957. Harefuah 1958; 54: 275-80; English \& French abstracts 80-1.

[8] Murgue B, Murri S, Zientara S, Durand B, Durand JP, Zeller H. West Nile outbreak in horses in southern France, 2000: the return after 35 years. Emerg Infect Dis 2001; 7: 692-6.

[9] Campbell GL, Marfin AA, Lanciotti RS, Gubler DJ. West Nile virus. Lancet Infect Dis 2002; 2: 519-29.

[10] Kramer LD, Li J, Shi PY. West Nile virus. Lancet Neurol 2007; 6: 171-81.

[11] Taylor RM, Work TH, Hurlbut HS, Riz KF. A study of the ecology of West Nile virus in Egypt. Am J Trop Med Hyg 1956; 5: 579620 .

[12] Murgue B, Murri S, Triki H, Deubel V, Zeller HG. West Nile in the Mediterranean basin: 1950-2000. Ann NY Acad Sci 2001; 951: 117-26.

[13] Bakonyi T, Ivanics E, Erdelyi K, et al. Lineage 1 and 2 strains of encephalitic West Nile virus, central Europe. Emerg Infect Dis 2006; 12: 618-23.

[14] Schuffenecker I, Peyrefitte CN, el Harrak M, Murri S, Leblond A, Zeller HG. West Nile virus in Morocco, 2003. Emerg Infect Dis 2005; 11:306-9.

[15] Komar N, Panella NA, Boyce E. Exposure of domestic mammals to West Nile virus during an outbreak of human encephalitis, New York City, 1999. Emerg Infect Dis 2001; 7: 736-8.

[16] Venter M, Human S, Zaayman D, et al. Lineage 2 west nile virus as cause of fatal neurologic disease in horses, South Africa. Emerg Infect Dis 2009; 15: 877-84.

[17] Tber AA. West Nile fever in horses in Morocco. Bull OIE 1996; 108: 867-9.

[18] Triki H, Murri S, Le Guenno B, et al. West Nile viral meningoencephalitis in Tunisia. Med Trop (Mars) 2001; 61: 487-90.
[19] Tsai TF, Popovici F, Cernescu C, Campbell GL, Nedelcu NI. West Nile encephalitis epidemic in southeastern Romania. Lancet 1998; 352: 767-71.

[20] Cernescu C, Nedelcu NI, Tardei G, Ruta S, Tsai TF. Continued transmission of West Nile virus to humans in southeastern Romania, 1997-1998. J Infect Dis 2000; 181: 710-2.

[21] Ceianu CS, Ungureanu A, Nicolescu G, et al. West nile virus surveillance in Romania: 1997-2000. Viral Immunol 2001; 14: 251-62.

[22] Ionescu A, Bria P, Rizac V, et al. Some preliminary studies assesing the presence of West Nile virus antibodies in horses in Romania. Proceedings of the International Veterinary Vaccines and Diagnostics Conference, Oslo 2006.

[23] Nicolescu G, Purcarea-Ciulacu V, Prioteasa L, et al. West NIle Virus in Romania. Report to the EDEN annual meeting 2009.

[24] Hubalek Z, Halouzka J, Juricova Z. West Nile fever in Czechland. Emerg Infect Dis 1999; 5: 594-5.

[25] Hubalek Z, Halouzka J, Juricova Z, Sebesta O. First isolation of mosquito-borne West Nile virus in the Czech Republic. Acta Virol 1998; 42: 119-20.

[26] Platonov AE, Shipulin GA, Shipulina OY, et al. Outbreak of West Nile virus infection, Volgograd Region, Russia, 1999. Emerg Infect Dis 2001; 7: 128-32.

[27] Hubalek Z, Halouzka J, Juricova Z, et al. Serologic survey of birds for West Nile flavivirus in southern Moravia (Czech Republic). Vector Borne Zoonotic Dis 2008; 8: 659-66.

[28] ProMED-mail. West Nile virus - Russia (Astrakhan) Archive Number 200509112688. 2005; Published Date 11-SEP-2005.

[29] ProMED-mail. West Nile virus - Russia (Rostov Region) Archive Number 200609252742. 2006; Published Date 25-SEP-2006.

[30] Joubert L, Oudar J, Hannoun C, et al. Epidemiology of the West Nile virus: study of a focus in Camargue. IV. Meningoencephalomyelitis of the horse. Ann Inst Pasteur (Paris) 1970; 118: 239-47.

[31] Pantheir R, Hannoun C, Oudar J, et al. Isolation of West Nile virus in a Camarge horse with encephalomyelitis. CR Acad Sci Hebd Seances Acad Sci D 1966; 262: 1308-10.

[32] Panthier R. [Epidemiology of the West Nile virus: study of an outbreak in Camargue. I. Introduction]. Ann Inst Pasteur (Paris) 1968; 114: 518-20.

[33] Panthier R, Hannoun C, Beytout D, Mouchet J. [Epidemiology of West Nile virus. Study of a center in Camargue. 3.-Human diseases]. Ann Inst Pasteur (Paris) 1968; 115: 435-45.

[34] Hannoun C, Panthier R, Mouchet J, Eouzan JP. [Isolation in France of the West Nile Virus from Patients and from the Vector Culex Modestus Ficalbi.]. C R Hebd Seances Acad Sci 1964; 259: 41702.

[35] Filipe AR, De Andrade HR. Arboviruses in the Iberian Peninsula. Acta Virol 1990; 34: 582-91.

[36] Filipe AR. Isolation in Portugal of West Nile virus from Anopheles maculipennis mosquitoes. Acta Virol 1972; 163: 61.

[37] Lozano A, Filipe AR. Antibodies against the West Nile virus and other arthropod-transmitted viruses in the Ebro Delta region. Rev Esp Salud Publica 1998; 72: 245-50.

[38] Cantile C, Di Guardo G, Eleni C, Arispici M. Clinical and neuropathological features of West Nile virus equine encephalomyelitis in Italy. Equine Vet J 2000; 32: 31-5.

[39] Mailles A, Dellamonica P, Zeller H, Durand JP, Zientara S, Moffette R. Human and equine infections in France, AugustSeptember 2003. Eurosurveillance 2003; 10/23/2003.

[40] Leblond A, Hendrikx P, Sabatier P. West Nile virus outbreak detection using syndromic monitoring in horses. Vector Borne Zoonotic Dis 2007; 7: 403-10.

[41] Kaptoul D, Viladrich PF, Domingo C, et al. West Nile virus in Spain: report of the first diagnosed case (in Spain) in a human with aseptic meningitis. Scand J Infect Dis 2007; 39: 70-1.

[42] Figuerola J, Soriguer R, Rojo G, Gomez Tejedor C, JimenezClavero MA. Seroconversion in wild birds and local circulation of West Nile virus, Spain. Emerg Infect Dis 2007; 13: 1915-7.

[43] Figuerola J, Jimenez-Clavero MA, Rojo G, Gomez-Tejedor C, Soriguer R. Prevalence of West Nile virus neutralizing antibodies in colonial aquatic birds in southern Spain. Avian Pathol 2007; 36: 209-12.

[44] Lopez G, Jimenez-Clavero MA, Tejedor CG, Soriguer R, Figuerola J. Prevalence of West Nile virus neutralizing antibodies in Spain is 
related to the behavior of migratory birds. Vector Borne Zoonotic Dis 2008; 8: 615-21.

[45] Esteves A, Almeida AP, Galao RP, et al. West Nile virus in Southern Portugal, 2004. Vector Borne Zoonotic Dis 2005; 5: 4103.

[46] Connell J, McKeown P, Garvey P, et al. Two linked cases of West Nile virus (WNV) acquired by Irish tourists in the Algarve, Portugal. Eurosurv Wkly 2004; 8.

[47] World Organisation for Animal Health - OIE. West Nile Fever, France. Immediate Notification 2006.

[48] Filipponi G, Lelli R, Savini G, et al. West Nile Virus surveillance in Italy: results of three years activities. 2005 National Conference on West Nile Virus in the United States, San Jose, California, February, 8-9 2005.

[49] Monaco F, Lelli R, Teodori L, et al. Re-emergence of West Nile Virus in Italy. Zoonoses and Public Health 2009:doi: 10.1111/j.863-2378.009.01245.x.

[50] Calistri P, Giovannini A, Savini G, et al. West Nile Virus Transmission in 2008 in North-Eastern Italy. Zoonoses and Public Health 2009; doi: 10.1111/j.1863-2378.2009.01303.x.

[51] Rossini G, Cavrini F, Pierro A, et al. First human case of West Nile virus neuroinvasive infection in Italy, September 2008 - case report. Eur Surveill 2008; 13.

[52] Gobbi F, Napoletano G, Piovesan C, et al. Where is West Nile fever? Lessons learnt from recent human cases in northern Italy. Eurosurveillance 2009; 14.

[53] Savini G, Monaco F, Calistri P, Lelli R. Phylogenetic analysis of West Nile virus isolated in Italy in 2008. Eurosurveillance 2008; 27: 13 .

[54] Malkinson M, Weisman Y, Pokamonski S, King R, Deubel V. Intercontinental transmission of West Nile virus by migrating white storks. Emerg Infect Dis 2001; 7: 540.

[55] World Organisation for Animal Health - OIE. West Nile Fever in Israel in geese. Dis Inform 1999; 12: 166.

[56] Chowers MY, Lang R, Nassar F, et al. Clinical characteristics of the West Nile fever outbreak, Israel, 2000. Emerg Infect Dis 2001; 7: 675-8.

[57] Weinberger M, Pitlik SD, Gandacu D, et al. West Nile fever outbreak, Israel, 2000: epidemiologic aspects. Emerg Infect Dis 2001; 7: 686-91

[58] Krisztalovics K, Ferenczi E, Molnár Z, et al. West Nile virus infections in Hungary, August - September 2008. Eurosurveillance $2008 ; 13$.

[59] World Organisation for Animal Health - OIE. West Nile Fever, Austria. Immediate Notification 2008.

[60] Gratz NG. The vector-borne human infections of Europe. Their distribution and burden on public health. World Health Organization Europe 2004.

[61] Kantzanou MN, Moschidis ZM, Kremastinou G, et al. Searching for West Nile virus (WNV) in Greece. Transf Med 2009; 19: doi: 10.1111/j.365-3148.2009.00964.x.

[62] Madic J, Savini G, Di Gennaro A, et al. Serological evidence for West Nile virus infection in horses in Croatia. Vet Rec 2007; 160: 772-3.

[63] Hubalek Z, Wegner E, Halouzka J, et al. Serologic survey of potential vertebrate hosts for West Nile virus in Poland. Viral Immunol 2008; 21: 247-53.

[64] Figuerola J, Jimenez-Clavero MA, Lopez G, et al. Size matters: West Nile Virus neutralizing antibodies in resident and migratory birds in Spain. Vet Microbiol 2008; 132: 39-46.

[65] Jimenez-Clavero MA, Sotelo E, Fernandez-Pinero J, et al. West Nile virus in golden eagles, Spain, 2007. Emerg Infect Dis 2008; 14: 1489-91.

[66] Malkinson M, Banet C, Weisman Y, et al. Introduction of West Nile virus in the Middle East by migrating white storks. Emerg Infect Dis 2002; 8: 392-7.

[67] Parreira R, Severino P, Freitas F, Piedade J, Almeida APG, Esteves A. Two distinct introductions of the West Nile Virus in Portugal disclosed by phylogenetic analysis of genomic sequences. VectorBorne Zoonotic Dis 2007; 7: 344-352.

[68] Rappole JH, Hubalek Z. Migratory birds and West Nile virus. J Appl Microbiol 2003; 94: 47S-58S.

[69] McLean RG, Ubico SR, Docherty DE, Hansen WR, Sileo L, McNamara TS. West Nile virus transmission and ecology in birds. Ann NY Acad Sci 2001; 951: 54-7.

[70] Banet-Noach C, Simanov L, Malkinson M. Direct (non-vector) transmission of West Nile virus in geese. Avian Pathol 2003; 32: 489-94.

[71] Baqar S, Hayes CG, Murphy JR, Watts DM. Vertical transmission of West Nile virus by Culex and Aedes species mosquitoes. Am J Trop Med Hyg 1993; 48: 757-62.

[72] Dohm DJ, Sardelis MR, Turell MJ. Experimental vertical transmission of West Nile virus by Culex pipiens (Diptera: Culicidae). J Med Entomol 2002; 39: 640-4.

[73] Miller BR, Nasci RS, Godsey MS, et al. First field evidence for natural vertical transmission of West Nile virus in Culex univittatus complex mosquitoes from Rift Valley province, Kenya. Am J Trop Med Hyg 2000; 62: 240-6.

[74] Nasci RS, Savage HM, White DJ, et al. West Nile virus in overwintering Culex mosquitoes, New York City, 2000. Emerg Infect Dis 2001; 7: 742-4.

[75] Romi R, Severini F, Toma L. Cold acclimation and overwinteing of female Aedes albopictus in Roma. J Am Mosq Control Assoc 2006; 22: $149-51$.

[76] Zhou G, Miesfed RL. Energy metabolism during diapause in Culex pipiens mosquitoes. J Insect Physiol 2009; 55: 40-6.

[77] Robich RM, Denlinger DL. Diapause in the mosquito Culex pipiens evokes a metabolic switch from blood feeding to sugar gluttony. Proc Natl Acad Sci USA 2005; 102: 15912-7.

[78] Filipponi G, Ciarrocca E, Savini G, Corsi I, Dell'Ariccia G, Lelli R. West Nile virus transmission in resident birds, Italy. IMED 2007 International meeting on emerging diseases and surveillance, Vienna (Austria), February 23-25, 2007.

[79] Rappole JH, Derrickson SR, Hubalek Z. Migratory birds and spread of West Nile virus in the Western Hemisphere. Emerg Infect Dis 2000; 6: 319-28.

[80] Fonseca DM, Keyghobadi N, Malcolm CA, et al. Emerging vectors in the Culex pipiens complex. Science 2004; 303: 1535-8

[81] Gomes B, Sousa CA, Novo MT, et al. Asymmetric introgression between sympatric molestus and pipiens forms of Culex pipiens (Diptera: Culicidae) in the Comporta region, Portugal. BMC Evol Biol 2009; 9: 262.

[82] Brown HE, Childs JE, Diuk-Wasser MA, Fish D. Ecological factors associated with West Nile virus transmission, northeastern United States. Emerg Infect Dis 2008; 14: 1539-45.

[83] Ewad PW. Evolution of Infectious Disease. New York, USA: Oxford University Press 1994.

[84] Hubalek Z. European experience with the West Nile virus ecology and epidemiology: could it be relevant for the New World? Viral Immunol 2000; 13: 415-26.

[85] Cabre O, Durand JP, Prange A, et al. [West Nile virus infection: serological investigation among horses in France and in Africa] Med Trop (Mars) 2005; 65: 439-43.

[86] Cabre O, Grandadam M, Marie JL, et al. West Nile Virus in horses, sub-Saharan Africa. Emerg Infect Dis 2006; 12: 1958-60.

[87] Chevalier V, Lancelot R, Diaite A, Mondet B, Sall B, De Lamballerie X. Serological assessment of West Nile fever virus activity in the pastoral system of Ferlo, Senegal. Ann NY Acad Sci 2006; 1081: 216-25.

[88] Reisen WK, Fang Y, Lothrop HD, et al. Overwintering of West Nile virus in Southern California. J Med Entomol 2006; 43: 344 55 .

[89] Reisen W, Chiles R, Martinez V, Fang Y, Green EN. Experimental infection of California birds with western equine encephalomyelitidis and St. Louis encephalitis viruses. J Med Entomol 2003; 40: 968-82.

This is an open access article licensed under the terms of the Creative Commons Attribution Non-Commercial License (http://creativecommons.org/licenses/by-nc/ 3.0/) which permits unrestricted, non-commercial use, distribution and reproduction in any medium, provided the work is properly cited. 